\title{
The legal Aspects of Privatisation in Cameroon. The Experience and the Lessons
}

\author{
By Atangcho N. Akonumbo, Yaoundé
}

\section{Introduction}

After thirty years of post-independence economic policy failures, most Sub-Saharan countries have, within Structural Adjustment Programmes (SAP) and pressure from international financial donors, like the International Monetary Fund (IMF), undertaken widespread liberalisation of their economies. As such, the States in this region are becoming more and more willing to transfer part of their patrimony to the private sector ${ }^{1}$. The privatisation of public and semi-public enterprises is therefore, one of the diverse ways towards such liberalisation. Although nearly two decades ago, proposals in view of making liberalisation through privatisation the cornerstone of economic policy, were not heeded to. ${ }^{2}$

Privatisation is a concept that was developed in the early Eighties to remedy the persistent difficulties of public enterprises. Since then, the concept has been expounded in most economic policies as a way to help governments relinquish themselves from the burden of managing those enterprises in favour of the ailing private sector, since in most cases they have proved to be bad managers.

In Cameroon, privatisation constitutes one of the structural reforms that government has put into place within the SAP to rescue the ailing economy. As in other countries, the process was fostered by far reaching changes in political systems and by information technology that has facilitated the globalisation of private business operations. ${ }^{3}$ The main objective of privatisation is to raise efficiency and to stop financial haemorrhage from loss

1 Kuoh, A., (1989), 'Les Privatisations des Entreprises Publiques: Un Nouveau Model de Développement en Afrique Noire Francophone', Thèse de Doctorat de 3è Cycle (Unpublished), Institut des Relations Inernatinales du Cameroun (IRIC), Yaoundé, p. 2.

Tamba, I., (1991), ' Les Déterminants de la Performance des Entreprises Publique en Afrique SubSaharienne: L'Exemple du Cameroun', Thèse de Doctorat de 3è cycle (unpublished), University of Yaoundé, p. 334. Reconstruction and Development / The world Bank, Washington, D.C, United States of America, p. 249. 
making public enterprises. The losses incurred by these enterprises have been enormous and the State at some point is financially exhausted. At the same time, international competition has intensified. Government has proved itself a bad manager showing lack of management and entrepreneurial skill. It usually finds it difficult to resist meddling with enterprises, through granting financial subsidies, controlling product or service prices for political reasons, creating State monopolies, turning a blind eye on unpaid taxes, and using such enterprises as a means of compensating 'political friends' with desirable positions. ${ }^{4}$ Thus, privatisation is one of the diverse formulae used to alleviate the persistent difficulties of public enterprises like poor management. It appears as a politic of helping a government match its role to its capacity. That is, leaving what is for the private sector and concentrating on its traditional duties; providing adequate social amenities as health, education, employment and security to its populace

However, financial and management problems have rendered the privatisation programme a very demanding task in Cameroon and the risks of failure are high. The process has been remarkably slow due to the lack of clearly defined policy and the mixing and confusion of roles. The organs in charge of the programme are under the direct influence of the political powers in place and their composition leaves much to be desired. In addition, too many incoherent texts have been issued between 1986 and 1997 to govern the programme.

The question of privatisation may not be considered new in Cameroon. In 1964 on the aftermath of independence, Government created a holding company - the National Investment Corporation (SNI). ${ }^{5}$ The prime objective of this company was to manage State portfolio in the private sector. However, it also had as mission, to participate in the development and industrialisation of Cameroon through the creation, nursing, and the eventual passing over of companies to the national private sector, once they become beneficial. This is a mild form of privatisation, though the transfer of those enterprises to the private sector is not for the same reason as under the ongoing privatisation programme and only started long afterwards. ${ }^{6}$ In fact, this is one of the peculiarities of the privatisation programme in Cameroon. The issues and different features of the programme may be discerned from a number of perspectives.

The World Bank's vice President and Secretary at the time, Timothy Thahane talking to the press on the World Bank's assistance for privatisation programmes in Africa: In: 'Bank's World', (July/August 1992), vol. 7/8, p. 14.

SNI is the French acronym, which stands for Societé National d'Investissement.

6 It was not until 1990 that Government's intention to actually privatise became clear with the passing of Ordinance No. 90/4 of June 22, 1990 relating to the privatisation of public and semipublic enterprises. In the same year, the Decree of implementation of this Ordinance was passed and later, another one published a list of the first 15 companies to be privatised - Decrees Nos. 90/1257 of August 30, 1990 and 90/1423 of September 3, 1990 respectively. 


\section{The Notion of Privatisation}

Privatisation is a term that designates the transfer of property from the public to the private sector involving large-scale structural changes. It involves all sales of public assets to private entities through offers, direct sales, management and employee buyouts, concessions or licensing agreements and joint ventures. ${ }^{7}$ Under the 1990 Ordinance governing privatisation in Cameroon, the concept of privatisation is taken to mean:

'...A transaction through which the State or public or semi-public body withdraws completely or partially from a corporation in which it owns all or part of the capital no matter its legal status (public establishment, State Corporation, mixed Investment Corporation or other) for the benefit of the private sector' ${ }^{8}$

Privatisation is therefore, a formula to dispossess enterprises of the public sector in favour of the private sector.

\section{The objectives of privatisation}

The basic objectives of the privatisation programme in Cameroon as enumerated in article 2 of the 1990 Ordinance are to:

- Streamline State finances through disengagement from public enterprises.

- Promote national and foreign investments;

- Restore market mechanisms with a view of increasing the efficiency of the management system of the economy; and,

- Mobilise the optimum channelling of domestic savings into productive investments.

These objectives indicate that privatisation is a medium for questioning the economic role of the State (since the State has proved itself a bad manager) and returning to the virtues of a market economy where it is the privileged role of the private sector to produce goods and services. The objectives of the privatisation programme in Cameroon may have a threefold target: ${ }^{9}$

The first is financial. Privatisation aims principally not only at reducing the State burden of subsidising ailing public/semi-public enterprises, but also at increasing public finances. To this end the 1990 Ordinance necessitates public calls for tenders to ensure that the best offer is got. This intention was clearly reflected in the 1999/2000 financial law, which stated that privatisation, had to contribute to the State budget, the sum of CFA 40 billion

7

8

9

The World Bank, (1998), op. cit., p. 285.

Article 1(1).

Ngankam, E.N., (1999), 'Privatisations: Faut-il Legitimer la Préférance Nationale? ', La Nouvelle Expression. No. 531 du 23 Juin 1999, p. 4. 
francs for the 1999/2000 financial year. Following the pace of the programme since it started, this could have seemed illusory because for example, within the ambit of the second standby agreement signed with the IMF, Government engaged to collect the sum of CFA 30 billion francs from privatisation sales before June 30, 1996. But that target was not met because by that date only 82.1 million US \$ (about CFA 4,5 billion francs) had been collected. That is, between 1990 and $1996 .{ }^{10}$ However, Government was able to raise a total of CFA 79 billion francs during the 1999/2000 financial year (as of June 30, 2000) with the sale of the second national telephone network - CAMTEL Mobile - for CFA 40.6 billion francs accounting for fifty per cent of the sum. The 2000/2001 financial law did not state any considerable amount (CFA 25 billion francs) but it was hoped that with the programmed sale of the major enterprises of the infrastructure domain (water, electricity, and telephone) within that period (2000/2001 financial year), the gains from privatisation would increase significantly. However, this was not the case because up to the last month of that financial year, none of such enterprises had been privatised; they were either undergoing restructuring or had been restructured or were awaiting final privatisation. Meanwhile, the 2001/2002 financial law has set the targeted income from privatisation at CFA 125 billion francs with the hope that all the said enterprises must have been privatised.

The second target, which directly complements the first, is economic. Privatisation normally orchestrates the amelioration of the quality of goods and services in addition to restoring the market mechanisms, through meaningful competition in the whole economy. For that to be possible, buyers of the enterprises must be capable of meeting up with the necessary degree of technology and management to ensure quality output. Thus, the technical exigencies should be clearly made in the invitations to tender. But the question is, if nationals are to be privileged buyers how do they go about the technical exigencies since they generally do not possess the know-how? Nationals cannot alone for example, cope with the financial and technical exigencies of companies like the Cameroon Telecommunications (CAMTEL) and Cameroon Airlines (CAMAIR).

The third target is strategic. It is primordial for any government (wishing to privatise to its nationals) to mobilise national savings towards productive investments and to reinforce the capacity of the national private sector. But in Cameroon this seems almost impossible because the rate of savings is estimated at 16 per cent of the Gross Domestic Product (GDP). This rate is low in relation to the country's level of development and its economic potential. The probable solution to have been envisaged would have been that privatisation should generate credit facilities. But as Ngankam (op. cit.) aptly questions, how can that be possible when there is no arena where the offer to buy will be supplemented by a request 
for financing, as obtains in the stock exchange market like the Bourse Régionale des Valeurs Mobiliers (BRVM) in West Africa? ${ }^{11}$

\section{The Mechanisms of Privatisation}

The term 'privatisation' as aforementioned designates the transfer of property from the public sector to the private sector. Under the 1990 Ordinance, such transfer may take various forms: ${ }^{12}$

- The total or partial transfers of property either in the form of shares or assets to the private sector;

- The acquisition of shares in the capital of the corporation or increase in the shares in the capital of the said corporation by natural persons or corporate bodies under private law, or the leasing of the assets of the corporation to such persons or bodies; and

- The signing of contracts for the management of a corporation in which the Government has shares with natural persons or corporate bodies.

The 1990 Ordinance goes further in a liberal spirit admitting any other recognised form of privatisation. ${ }^{13}$ An example that may be implied here is allowing the private sector to provide services hitherto provided by the State or municipal authorities such as concessions or franchises. But it should be emphasised that generally, the concept of privatisation despite the above mentioned liberal spirit of the 1990 Ordinance hardly entails any of the following neighbouring situations which might easily lend confusion to the various mechanisms of privatisation:

- the establishment of a public enterprise institutionally separate from the Government 'Corporatisation';

- the reorganisation of a public enterprise along commercial lines to make it more efficient - 'Commercialisation'; or

- the liberalisation of regulatory barriers to encourage competition from private firms, and/or the breaking up of a public enterprise into smaller units - 'De-monopolisation'. ${ }^{14}$

Ngankam, E.N,. op. cit., p. 4 supra; Akonumbo A.N., (1998), 'The Legal Framework for the Protection of Foreign Direct Investments in Cameroon', Doctorat de Troisième Cycle Thesis (Unpublished), University of Yaoundé II, p. 226.

Article 3 (1).

13 Ibid.

14 UNCTAD [United Nations Centre on Trade and Development], (September 14, 1993), 'The Role of Policy In Economic Reforms In Developing and Other Countries' UNCTAD/TD/B/RDP/96. pp. 22 et seq. 
However, de-monopolisation is a mild form of privatisation. It was adopted in the case of the Société de Développement du Riz de Yagoua (SEMRY). The industry no longer has the monopoly to buy paddy rice from villagers and the winning factory was closed down altogether. Also, the breaking up formula of an enterprise into smaller units is adopted by the August 30, 1990 Decree to implement the 1990 Ordinance. This Decree admits the splitting of an enterprise into smaller distinct entities whose privatisation may be done severally following any of the diverse methods prescribed by the Ordinance. ${ }^{15}$ The period of privatisation may be during liquidation or following the dissolution and liquidation of the public enterprise. $^{16}$

Another important feature of the Cameroonian mechanism of privatisation under the 1990 Ordinance that is salutary is that it necessitates transparency in the operation. This serves as assurance to public opinion, which already deems the on-going programme as a threat to national sovereignty. ${ }^{17}$ In this light, the Ordinance provides guiding principles for the programme. These principles include the prior and proper valuation of the corporation to be privatised and, the necessity for public calls for tenders. ${ }^{18}$ This two-fold guide may present a two-fold impact. First, in the interest of the State, it ensures that a corporation is not sold at a token rate. Secondly, (and this is in the interest of prospective buyers and the public) that there must have been a prior scrutiny of the various tenders so as to obtain the best offer. This, in other words, guarantees competitiveness between the prospective buyers thus assuring transparency of the operation. However, what seems to stifle this legislative effort is the fact that the very Ordinance allows for the possibility to side step those guidelines. Article 4 of the Ordinance states: '... However the preceding provision may be waived under conditions to be fixed by decree'.

Consequently, article 16 of the August 30, 1990 Decree provides derogation from its article 11 (in conformity with article 4 of the Ordinance). Article 11 of the Decree necessitates the prior valuation of the enterprise to be privatised and the need for competition through tenders. But under article 16, these conditions may be waived in favour of:

- A wider participation of civil servants and other State agents as well as, small Cameroonian savings holders in the privatisation of the enterprise;

- The participation of salaried workers in the capital of the enterprise or even the total take-over of the enterprise by such workers;

15

16

17

18
Article 5 .

Article 3(2) of the Ordinance.

Since most of the public enterprises in the strategic domains of energy, telecommunication and transport have been slated for privatisation.

Article 4 of the Ordinance; Articles 11 and 12 of the August 301990 Decree. 
- The participation of farmers' or livestock breeders' groupings or co-operatives in the privatisation of an enterprise of an agricultural vocation; and

- The acquisition of new technology.

Such derogation only helps to impede the privatisation programme through bureaucratic hurdles and consequently promotes the fear of its non-transparency. This may explain some of the problems encountered by the programme.

\section{The Conditions of Privatisation}

The question here is: who is eligible to buy over an enterprise to be privatised, and under what conditions? A priori it should be noted that the 1990 Ordinance clearly indicates who may be a potential buyer and here, the liberal spirit of the Ordinance can be clearly noticed. As such, only the following persons could be buyers: private nationals (natural persons or corporate bodies), civil servants and State employees, the personnel of public or semipublic enterprises and foreign investors. Again, any of the above mentioned prospective buyers must satisfy two very important conditions, namely:

- Have a comfortable financial base; and

- Possess sufficient know-how and recognised technical capabilities. ${ }^{19}$

However, as shall be seen later, these are onerous exigencies for nationals. ${ }^{20}$

\section{The Institutional Framework}

At the very beginning of the privatisation programme in Cameroon was the Decree of June 3, 1986. ${ }^{21}$ This Decree created a Commission for the Rehabilitation of Enterprises of the Public and Semi-public Sectors (hereinafter referred to as 'The Commission'). The Commission was later to become the basic competent organ to manage the programme. The Commission was placed under the authority of the Secretary General at the Presidency of the Republic. ${ }^{22}$ It was charged with the task of proposing to the Head of State avenues for eradicating and preventing the causes of the persistent difficulties of public and semi-public

19

20

21 Decree No. 86/656 of June 3, 1986 to create a Commission for the Rehabilitation of Enterprises of the Public and Semi-public Sector.

Ibid. Article 1. 
enterprises. ${ }^{23}$ It comprised two organs, viz.: an Inter-ministerial Committee and a Technical Committee. $^{24}$

The objectives of The Commission under the 1986 Decree did not include privatisation ${ }^{25}$. The Inclusion was only done later in the March 29, 1995 Decree to reorganise The Commission, ${ }^{26}$ in pursuance of a 1989 Law, ${ }^{27}$ which authorised the President of the Republic to define by Ordinance, the regime of privatisation of enterprises of the public and semipublic sectors. In 1990 therefore, the scope of The Commission's tasks had to be revised since privatisation was now included within the purview of its management with the advent of the February 27, 1990 Decree, ${ }^{28}$ and later, the 1990 Ordinance.

Under the 1995 Decree, the main function of The Commission is to 'assist the Head of State in the definition, orientation and evaluation of his policy on matters of rehabilitation of public and Semi-public enterprises' ${ }^{29}$ (instead of making proposals as was the case under the 1986 Decree). Under 1995 Decree therefore, the Head of State is the master of the programme and as a result, the powers of The Commission curbed. ${ }^{30}$ The Decree however maintains that The Commission comprises an Inter-ministerial Committee and a Technical Committee. $^{31}$ The Technical Committee was later split into two separate restructured Technical Committees by the first of a January 3, 1997 trilogy of decrees; ${ }^{32}$ one in charge of privatisation and liquidation, and the other, the rehabilitation of enterprises of the public and semi-public sector. Each of the new Technical Committees has a precise mission to accomplish. This, it is hoped, will eliminate the inherent problem of delays, improve on the

Ibid. article 3.

Ibid. article 4.

Article 3, supra

26 Article 1 of Decree No. 95/056 of March 29, 1995 to modify some provisions of decree No. $86 / / 656$ of June 3, 1986. Law No. 89/030 of December 29, 1989

Decree No. 90/428 of February 27, 1990 to modify certain provisions of the 1986 Decree. This Decree instituted a Sub Technical Committee in charge of privatisation. (Article 5(2)). Article 1 Surpra. (My translation).

30 See for example article 4 (1) and (2).

Article 2.

32 These decrees are: Decree No. 97/1 of January 3, 1997 to modify some provisions of Decree No. 95/056 of March 291995 to reorganise The Commission for the Rehabilitation of Undertakings of the Public Semi-public Sector; Decree No. 97/2 0f January 3, 1997 to lay down the organisation and functioning of the Technical Committee for the Rehabilitation of public and semi-public Corporations; Decree No.97/3 0f January 3, 1997 on the organisation and functioning of the Technical Committee for the privatization and liquidation of enterprises of the public and semipublic sector. 
performances of Organs of the Commission and possibly speed up the programme. Moreover, new units have been created within the new Technical Committees each having a precise mission to accomplish. Thus, reducing the problem of confusing and meddling with the affairs by the officials of the Organs handling the programme.

The decision-making organ The Commission is the Inter-ministerial Committee, chaired by the Minister of the Economy and Finance ${ }^{33}$ (instead of the Secretary General of the Presidency as was the case under the 1986 Decree). ${ }^{34}$ An August 30, 1990 Decree $^{35}$ sets out the functions of the Inter-ministerial Committee. It draws up the list of the enterprises to be privatised and, fixes the mode of privatisation and price or royalties for each case. It decides on eventual preparatory measures to be put in place before the privatisation of the enterprise, recommends accompanying measures on issues of privatisation and the basis of evaluations. Also, it fixes parameters to be integrated in each document of privatisation, draws up the final list of buyers and, signs on behalf of the State and public organisations documents and acts relating to privatisation. Furthermore, it ensures the respect of contractual terms, assures follow-up and, treats problems arising within the framework of any privatisation and liquidation. ${ }^{36}$

The Technical Committee in charge of Privatisation and Liquidation (herein after referred to as 'The Committee') on its part is the technical organ of The Commission. The Committee is under the authority of the president of the Inter-ministerial Committee - The Minister of the Economy and Finance. The Minister Delegate in charge of the Stabilisation Plan for Public Finances and Economic Recovery supervises The Committee and directly ensures the constant follow up of its activity, under the authority of the Minister of the Economy and Finance. ${ }^{37}$ The Committee has a chairman and a vice. The chairman co-ordinates the meetings of The Committee and ensures its smooth functioning. In conformity with article 8, of the 1986 Decree and article 5(2) of the third of the January 3, 1997 trilogy of decrees, the chairman of The Committee reports on its activities directly to the president of the Inter-ministerial Committee. ${ }^{38}$ The Committee comprises four Units namely, a Liquidation Unit, an Administrative and Financial Unit, an Accounting Unit, and Technical Units. ${ }^{39}$

Article 3(1) of the 1995 Decree. The Committee is comprised of: the minister in charge of the plan, stabilisation of public finance and economic recovery; the minister in charge of industry, the tutelage minister of the enterprise concerned; the representative of the Secretary General of the Presidency; the representative of the Prime Minister's service; and, the director general of the SNI.

Article10 (2) of the June 3, 1986 Decree.

35

Decree No. 90/1257 of August 30, 1990 to implement the 1990 Ordinance.

Ibid. article 8 .

37

Article 7(2) [new] of the first decree of the January 3, 1997.

Article 4 (2) and, 5(1) and (2) of the third Decree of January 3, 1997.

39

Ibid. article 4 (3). 
With respect to its functions, The Committee proposes the annual programme of privatisation on the basis of analysis of State portfolio and carries out all prior studies deemed necessary for the technical preparation of the privatisation. It evaluates each enterprise to be privatised, and advises the Inter-ministerial Committee on the choice of the mode of privatisation. It carries out eventual preparatory measures and prepares the accompanying measures of privatisation operations. The Committee prepares the file of each enterprise to be privatised, makes tenders and receives offers, examines, evaluates and hands to the Inter-ministerial Committee the list of the better-placed ones. The committee is also charged with the supervision and control of liquidations of public and semi-public enterprises. 40

These functions were formally carried out by the defunct Sub Committee in charge of privatisation of the defunct Technical Committee but for the following; to propose the annual programme of privatisation on the basis of analysis of State portfolio and carries out prior studies deemed necessary for the technical preparation of the privatisation; to ensure the follow up of an enterprise undergoing privatisation; and, to ensure the follow up of the enterprise within a period determined by the Inter-ministerial Committee after the signing of documents evidencing the transfer of title. ${ }^{41}$ This means that the scope of The Committee has been widened. However, The Committee has been stripped of the function of following up and treatment of problems relating to privatisation and liquidation.

\section{The Problems of Privatisation}

The problems of privatisation in Cameroon can be viewed from a number of perspectives viz.

\subsection{Public Opinion with respect to the programme}

Public opinion in Cameroon on this issue of privatisation has been tainted with fears, that Government is engaged in a considerable 'Mafia' to sell State corporations for token rates. That is why, one Cameroonian opinion referring to the ongoing privatisation programme states: 'La privatisation se poursuit dans le noir'. ${ }^{42}$ Even international experts find it diffi-

40

41

42 
cult to define the nature of the programme in Cameroon. Xavier Inock for example states that 'The privatisation carried in Cameroon remains ambiguous and even fallacious and does not in any way respond to restructuring and deregulation of old economies in the world'. 43

Yet, the August 30, 1990 Decree clearly states ${ }^{44}$ that in accordance with article 4 of the 1990 Ordinance, enterprises to be privatised shall be subjected to recognised and currently applied objective methods of valuation. This includes taking into account in each case; the mode of privatisation adopted the material value of the enterprise, as well as, its turn over. The Decree also stresses that competition in offers should result from invitations to tender and enough publicity. Indeed, in the case of the privatisation of La Société des Hévéas du Cameroun (HEVECAM) and Cameroon Shipping Lines (CAMSHIP - though it is still in course of being privatised) wide publicity and invitations to tender were made. The up-shot of this is evident because HEVECAM for example, was sold in 1996 to GMB Panwell of Indonesia, for CFA 23 billion francs indicating that the operation was fruitful. Meanwhile, cases where the privatisation was lobbied behind closed doors with foreign "friends" have been sad. For example, some companies were sold for token rates; L'Organisation Camerounaise de la Banane -OCB (banana company) sold for CFA 513 million francs, ${ }^{45}$ La Société d'Exploitation des Parcs de Bois duCameroun - SEPBC (timber company) for CFA 813 million francs, ${ }^{46}$ and Contre Plaqués du Cameroun-COCAM (timber company) for CFA 480 million francs.

From the values of those above mentioned privatisation sales, one consequence stands out clearly namely, that in the absence of sufficient calls for tenders and enough publicity lucrative enterprises are privatised for token rates. This only goes to confirm the disdain with which Cameroonians are viewing the programme. In fact, banana and timber are some of, if not, Cameroon's top primary products, which command high quality in the international market. But it is unbelievable that enterprises engaged in these fields are to be privatised for such token rates. There is a true fear that the Government is putting up a smoke screen on the privatisation programme such that, the programmed revival of the private sector remains dormant. None of the above-mentioned timber or banana companies should have been sold for at least CFA 8 billion francs.

CAMTEL Mobile and HEVECAM that some transparency was observed as sufficient publicity and tenders were made; L'Expression, (février 1997), 'Les Dessous des Privatisations', Dossiers et Documents, $\mathrm{N}^{\circ} .2$, p. 2.

Cited in, L'Expression, op. cit., p. 2, supra. The statement is in French. This is my translation. Article 11.

45

46

L'Expression, op. cit., p. 7.

47

Ibid.

Ibid. 
The foregoing may appear to be trivial but it may greatly affect negatively the investment climate prevailing in the country. This is evident from the stand point of the fact that, of the over forty companies ${ }^{48}$ that have been slated for privatisation since 1990, only twelve as of January 1997 had been privatised either totally or partially, following any or all of the diverse forms provided under the 1990 Ordinance. The total proceeds of the sales amounted to US \$ 41.1 million. ${ }^{49}$ That is enough indication that the privatisation process is slow and very un-lucrative. An even more concrete example is the fact that of the first list of fifteen companies $^{50}$ that were enlisted for privatisation by a Presidential Decree of October 3, 1990 only six ${ }^{51}$ had been totally privatised by 1994 amounting to CFA 3,8 billion francs. The privatisation of five other companies failed and two other companies were withdrawn from that list of fifteen. The second list of fifteen companies ${ }^{52}$ was set forth by another Presidential Decree of July 14, 1994. Of this group only one enterprise has gone on complete privatisation - HEVECAM. The remaining fourteen have either been slated for liquidation or put under the other related forms of privatisation. For example, concerning the Société de Raffinage du Littoral (SRL), the State shares were transferred to the Fadil group in 1995, and with the SCT the State privatised only the management and retained the assets. ${ }^{53}$ Since 1997, the number of sales has increased timidly ${ }^{54}$ and statistics as of June 30,2000 indicate that eighteen public or semi-public enterprises have so far been privatised, while the privatisation of nine others is imminent. ${ }^{55}$ However, Government seems to be revising its strategy by opting for meaningful invitations to tender especially as concerns the new phase of the privatisation programme which has begun involving strategic enterprises of the infrastructure domain such as energy (SONEL), water (SNEC) and telecom-

PNUD [Programme des Nations Unies Pour le Développement], (1997), 'Rapport sur le Développement Humain Au Cameroun 1996: Secteur Privé et Développement Humain ', PNUD, Yaoundé, p. 49; L' Expression, op. cit., p. 7; Jeune Afrique Economie, (1996), op. cit., pp. 221225.

The World Bank, (1999), 'World Development Indicators 1999', The World Bank/IBRD, Washington, D.C: USA, p. 298. Proceeds from privatisation in the World Development Indicators include all sales of public assets to private entities through public offers, direct sales, management and employee buyouts, concessions or licensing agreements and joint ventures ( at p. 301).

See L'Expression, (1997), op. cit., p. 7. Supra; Jeune Afrique Economie, (1996), op. cit., pp. 221 $\& 222$.

The six are: SOFIBEL (sold for CFA 1,45 billion F), COCAM (sold for 480 million), SCDM (sold for 300 million), SEPBC (sold for 1,813 billion), SOCAMAC (sold for 814 million), and OCB (sold for 513 million).

Jeune Afrique Economie, (1996), op. cit., pp. 223 \& 224.

53

PNUD, (1997), op. cit., p. 49; L’Expression, op. cit., p. 7, supra.

54 For example, the privatisation of SOSUCAM, SOCAPALM, CAMSHIP, BICEC (51\%), REGIFERCAM, (now CAMRAIL - Cameroon Railways) and CAMTEL Mobile. 
munications (CAMTEL). The aim of this revision of strategy is probably to increase the number and the values of the sales. The sale of the second national telephone network CAMTEL Mobile for example, for CFA 40 billion francs as aforementioned, is indicative. This sale represents so far the most successful and valuable sale from a single operation in the ongoing privatisation programme in Cameroon.

\subsection{The Institutional Framework}

The institutional framework is a major source of problem to the ongoing privatisation programme. Some of the incongruities plaguing the organs in charged of the programme may be single out.

1. The March 29, 1995 Decree seems to set confusion and contradictions with regard to the enactment before it which had clearly laid down the functions and competence of the various organs managing the programme. The Decree states for example that the Interministerial Committee initiates documents and makes proposals to the Head of State as regards; the list of enterprises to be privatised, restructuring modalities, privatisation and/or liquidation, and the choice of potential buyers. The examined documents are transmitted to the Prime Minister, who shall diligently submit the same to the utmost sanction of the Head of State backed by his (Head of State's) reasoned opinion. The Head of State's directives are then communicated to the president of the Inter-ministerial Committee for execution, and to the Prime Minister for follow-up. 56

The above mentioned, clearly represents a panoply of new functions for the Inter-ministerial Committee with the Head of State's omnipresence highly felt. These new functions seem (?) to contradict and conflict with the functions of the Inter-ministerial Committee clearly set out in article 8 of the Decree of August 30, 1990. ${ }^{57}$ This 1990 Decree vests entirely, the management of the privatisation processes in the hands of the Inter-ministerial Committee. Seemingly, and pretending not to contradict the proviso (article 8), the 1995 Decree proceeds (in article 5) to take cognisance of the said article 8 by subjecting article 5 to it (article 8). But in doing so only blurs the situation. It states that the president of the Inter-ministerial Committee shall regularly report to the Head of State and the Prime Minister for purposes of evaluation and acceleration of the activities of the Committee without prejudice to the disposition of article 8 of the August 30, 1990 Decree. This is a subtle sidestepping of the competence of the Inter-ministerial Committee as stated in article 8 of the 1990 Decree. 
2. Also, in 1994 while defining the list of fifteen enterprises to be privatised the controversial situation just mentioned had been initiated. Article 2 of the Decree of July 14, $1994^{58}$ provided that the modalities of privatisation, or as the case may be, of liquidation of targeted enterprises had to be determined case by case by the Prime Minister after approval by the President. This was contrary to article 3 of the 1990 Ordinance, which impliedly, attributed this function to the Inter-ministerial Committee. ${ }^{59}$ Article 2 of the July 14, 1994 Decree therefore obviously contradicted articles 8 (2) of the August 30, 1990 Decree. For this reason, the said article 2 had to be expressly repealed in article 8 of the March 29, 1995 Decree.

3. Even more uncertainty is brought in by article 7(3) of the 1995 Decree. It gives room for, delays through the exercise of administrative discretion (on how and when to conceive a new text) and, the proliferation of new texts. The article states that, the organisation and functioning of The Committee shall be fixed by decree of the President based on proposal by the president of the Inter-ministerial Committee - The Minister of the Economy and Finance. Consequently, four decrees have seen the light of day since March 1995. That is, between 1995 and January 1997; a February 7, 1996 Decree $^{60}$ and, the January 3, 1997 trilogy of decrees. These decrees have attempted to give a face-lift to the programme by redefining the organs handling it and their competence.

It is uncertain why up to three decrees were passed on the same day in January 1997 whereas their contents could have as well been brought under one decree namely, the first. The January 1997 Decrees sought to enhance the prospects in article 7(3) of the March 1995 Decree, namely, the redefinition of the organisation and functioning of the Technical Committee. The first of the decrees is consecrated to the creation of two Technical Committees (though this was not in the spirit of article 7(3) above) while the second and third respectively focus on the organisation and functioning of each of the two Committees. This proliferation of texts may seem amazing but it is standard practice in Cameroon. The first of the January 1997 trilogy of Decrees therefore does not go beyond creating two Technical Committees and advancing a limited aspect of their competence, namely that they (the two new Technical Committees) shall work hand in hand. ${ }^{61}$

Decree no 94/125 of July 14, 1994 to admit certain enterprises of the public and semi-public sector in the privatisation process.

Article 8 (2) of the of August 30, 1990 Decree, which clearly states that the Inter-ministerial Committee shall fix for each case the mode of privatisation in conformity with article 3 of the 1990 Ordinance. This article states: '...the practical conditions of the privatisation shall be fixed by separate instruments'. That had already been done in the Decree of August 30, 1990.

Decree No. 96/023 of February 7, 1996 to modify certain provisions of Decree No. 95/056 of March 29, 1995 reorganising the Commission for the Rehabilitation of Enterprises of the public and semi-public Sector.

Article 7 (3) [new] of the first decree of January 3, 1997. 
4. As aforementioned, the chairman of The Committee reports directly to the Minister of the Economy and Finance on its management and functioning. But this seems curious because, the Minister Delegate in charge of the stabilisation and Economic Revival Plan is the one who directly ensures the constant follow-up of The Committees' activities ${ }^{62}$ and as such it would have been obvious instead that the chairman of The Committee reports to him who shall in turn report to the Minister of the Economy and Finance. However, perhaps the reason for adopting that position is to avoid delays but this will be contrary to the competence of the Minister Delegate.

The third decree of January 3, 1997 reforming the functioning and organisation of The Committee provides in article 6 that the chairman may, subject to approval by the Minister Delegate invite any person to deliberations of The Committee by reason of his expertise. There is clearly here, no room for freedom of choice since the Minister Delegate (?) may arbitrarily discard the chairman's reasonable choice (?). In other words, the chairman's discretion which on its part, should not be exercised as a matter of grace or with arbitrariness may instead be subjected to the Minister Delegate's own arbitrary discretion in rejecting or even accepting the chairman's choice. As such, the chairman is not really free to make a choice that he may deem reasonable (?).

The same decree (third) also gives room for delays. Issues are once more pushed for treatment by future instruments. The decree states that the Technical Units assigned with specific duties relating to the privatisation of an enterprise or a group of enterprises are to be created and organised by Ministerial by Order of the Minister of the Economy and Finance.

5. Furthermore, hopes of entrusting the management of the programme in the hands of experts as intimated in articles 6 and 13 (2) of the decree are blurred. Article 13(1) states that The Committee works in close collaboration with Government services involved in the privatisation programme. The services are not even indicated. This gives room for justifying intervention by unauthorised (Government) officials in the privatisation process thereby confounding and confusing it. The question is why even recognise such services when there are specialised organs already in charge of the programme? This is only a means of entrusting the management of the programme to Government officials rather than to experts. Consequently, the privatisation process is essentially a matter of the Sate and Statesmen. 
6. There is yet a problem of indecision inherent in some of the various texts governing privatisation in Cameroon and this is a consequence of turning out too may texts to govern one issue. The risk is bringing in trivialities and eliminating serious issues. For example, a vivid transparency tool entailed in the June 3, 1986 Decree has been systematically deformed within subsequent texts thereby diluting its initial propriety. Article 6 (1) of the Decree provides that in the execution of its functions, the (defunct) Technical Committee shall work with the technical assistance of the World Bank and may also call on other specialised organisations. Under the August 30, 1990 Decree, it was modified that the defunct Sub-Committee in charge of privatisation of the defunct Technical Committee could be assisted in the execution of all its of functions outlined therein by national and/or foreign experts. In 1995 this provision was carefully uplifted by the March 29, 1995 Decree which suspended the functioning of the Committee and subjected it to subsequent redefinition. It follows that necessity to recourse to the assistance of the World Bank was deleted. The reason probably is that the World Bank would have had a positive insider influence in the Committee serving as a watchdog - putting a check to any malpractice. However, the idea has been revived and restated in article 6 of the third decree of January 3, 1997 but in a highly diluted manner. The article states that, the chairman of The Committee may associate any competent person to the activities of The Committee subject to the approval of the Minister Delegate in charge of the Stabilisation and Economic Recovery Plan. Thus, the express preference to The World Bank is carefully avoided and left to the discretion of the chairman of The Committee and the Minister Delegate on the one hand, and the Minister of the Economy and Finance on the other. ${ }^{64}$

7. Again, It is rather curious that none of the decrees since 1986 addresses the issue of sanctions against the members of the various organs (especially The Committee) in the event of misadministration, mismanagement corruption and/or embezzlement. And since for example the services of the president and the members of the Inter-ministerial Committee for example, are non-remunerative, ${ }^{65}$ there is reason for lack of seriousness.

8. The proliferation of texts to govern the privatisation programme may be very dangerous and such texts may involve irrelevancies. It shall been seen below ${ }^{66}$ for example, that the 1996 Decree was a dangerous attempt. Also, some new texts only echo word verbatim, previous provisions in previous texts thus bringing in nothing new or significant. ${ }^{67}$ Moreover, such unnecessary repetitions may lead to another hazard, namely, contradictions. For example, the first decree of January 3, 1997 states that Technical Committee(s) assist the

Ibid. articles 6 and 13(2) respectively.

Article 6 of the March 1995 Decree.

See 7.3

Article 7(2) (new) and 4(2) of the first and third Decrees of January 3, 1997 respectively. 
Inter-ministerial Committee in its functions. The third decree of January 3,1997 states that The Committee is attached to the Inter-ministerial Committee. In other words, the former decree gives the impression that The Committee barely assists and is not part of the Interministerial Committee; while the latter decree gives the impression it is actually part of it.

It is therefore evident that the institutional framework governing privatisation in Cameroon is too heavy. The functions of the various organs in charge remain confused and uncertain.

\subsection{The Legal Framework}

The legal framework governing the privatisation programme in Cameroon as earlier mentioned, is choked with two many instruments enacted between 1986 and 1997 (- at least nine-) which are essentially ambiguous and sloppy. ${ }^{68}$ For example, the February 7, 1996 Decree was a complete sham. It was characterised by substantive errors, which further confused and delayed the privatisation process. Not only was the previous August 30, 1990 Decree wrongly quoted ${ }^{69}$ in the introductory part (of the 1996 Decree), but the article of the March 29, 1995 Decree sought to be modified was wrongly quoted. In effect, the 1996 Decree sought to modify article 7 of the 1995 Decree but instead quoted article 6 . It is surprising how such an error could go unnoticed from the time of the conception of the decree right up to time of signature. This only indicates the carelessness and lack of seriousness with which the authorities in charge are treating the privatisation programme. The 1996 Decree was only repealed in 1997 by article 2 of the first decree of January 3, 1997 trilogy. But it had nevertheless, already made its own cut in the evolution of the

(a) Ordinance No. 90/004 of June 22, 1990 on the Privatisation of Public and semi-public Enterprises.

Decree No. 1257 of August 30, 1990 to implement Ordinance no. 90/004 of June 221990.

Decree No. 86/656 of June 31986 to create a Commission for the Rehabilitation of public and semi-public enterprises (and its amended versions).

Decree No. 94/125 of July 141994 to admit certain enterprises of the public and semi-public sectors into the privatisation process.

Decree No. 95/056 of March 29, 1995 to reorganise the Commission for the Rehabilitation of Enterprises of the public and semi-public sector.

Decree No. 90/428 of February 27, 1990 to modify certain provisions of Decree No. 86/656 of June 31986 on the creation of a Rehabilitation Mission of public and semi-public enterprises (and its amended versions).

Decree No.90/1423 of October 3, 1990 to privatise certain enterprises of the public and semipublic sector. (This Decree published the first 15 enterprises to be privatised).

Decree NO. 97/ 01 of January 3, to modify some provisions of the March 29, 1995 Decree.

Decree No. 97 / 03 of January 3, 1997 to reorganise the organisation and functioning of the Technical Committee for the privatisation and liquidation of enterprises of the public and semipublic sector

69

It was quoted as Decree No. 90/1257 of August 30, 1986 instead of, Decree No. 90/1257 of August 30, 1990. 
programme; it served as an unnecessary interlude in an already slow and un-pragmatic process.

The legal framework governing both the institutional framework and the functioning of the programme is choked with too many instruments. And worse still, new instruments instead of clarifying previous ones do not only add to the existing ambiguities but also postpone many issues to be taken care of by future enactment(s)

There is a further problem of translation of texts. Since Cameroon is a bilingual country all laws are published in the two official languages, French and English. Since a text is conceived in one of the official languages (usually French) it has to be translated to the other. In this process of translation, errors may slip in thereby deforming the sense of a provision. For example, article 7(3) new of the first decree of January 3, 1997 is poorly translated from French to English. The French version reads: 'Lorsque le Comité interministériel siège, son secrétariat est assuré, selon le cas, par la Commission compétente sur la matière inscrite a son ordre du jour....' Meanwhile, the English version reads: Whenever the Inter-ministerial Committee meets, its secretariat duties shall be performed, as the case may be, by the Committee that is competent on the agenda item.... Again, article 3(2) of the third decree of January 3, 1997 reads: 'Après la signature des documents juridiques concernant le transfert de propriété ou de responsabilité dans l'entreprise... admise a la procedure de privatisation...'. The English version reads: 'After the signing of the legal documents concerning the transfer of proprietorship or responsibility in a ...corporation under the privatisation process...' Coupled with the fact that the legal framework is overcrowded with texts, the natural upshot is uncertainty and confusion. Certainly, one may base an analysis on a repealed text not knowing or, on a poorly translated version, which is dangerous. This is a common problem with the legal framework governing different issues in Cameroon. The problem of proliferation of texts has led to what professor C.N. Ngwasiri and others aptly describe as uncertainty of law. ${ }^{71}$ They explain the situation and its possible intricacies thus:

'As regards proliferation of laws, it is common knowledge in Cameroon that the administrative authorities churn out thousands of texts every year, some of which contradict previous ones. It is thus possible for opposing lawyers defending their clients in court to cite different but subsisting laws in support of their arguments and both would be right. The greatest danger here is that it is possible that a judge who decides such a case, might do so, not on the basis of the law (which arguably does not exist), but according to what he thinks ought to be the law, that is, at his discretion .In such a

For example, article 7 (3) of the March 291995 Decree, article 12(2) of the third decree of January 3, 1997.

71

Ngwasiri C.N., et al., (1997), The Informal Sector in Douala - Cameroon: A Survey of Street Vendors, Yaounde, p. 34; Akonumbo, A.N., op. cit., pp. 162-166. 
system, the discretionary powers of the judges become the law, and it can be argued that everyone is at one time or another breaking the law. A World Bank study could thus conclude that the result of the law making process in Cameroon is that "economic agents are never certain of the exact scope, precise meaning or real impact of new legislation" ' 72

\subsection{Absence of a Sound Regulatory Environment and a Sustainable Private Sector ${ }^{73}$}

A more serious problem hampering the privatisation programme is that Cameroon's private sector is greatly weakened by non-facilitative regulations. There is an onerous procedure for establishing new enterprises. A panoply of legal and administrative prerequisites involve certain costs, namely, the cost of registering a business and the costs which have to be borne by operating in accordance with the official requirements. The result of the tedious process is that most businesses in the major cities in the country for example, operate within the informal sector. This sector has realised a rapid expansion. In the economic capital Douala for example, a sample study revealed that 96,690 street vendors and over ninety percent of 21,235 SMEs operate on the margin of the law because they find it difficult to operate in accordance with official regulations. ${ }^{74}$ To this end, the authors of the study maintain:

' "Privatisation" and "performance contracts", cited by Lindenberg have both been tried in Cameroon. They too have not yielded the desired results. We have argued that Cameroon's regulatory infrastructure is in ruins. No amount of repair work can save the edifice, which can no longer withstand the weight of regulations'. ${ }^{75}$

Also, there is no sustainable private sector in Cameroon to buy the privatisable enterprises. Efforts geared towards instituting one have more often than not failed. Two examples are instructive here. First, the SNI, which was aimed at instituting a sustainable private sector, has been a failure. With a capital of CFA 13 billion francs at creation, the World Bank described it as 'a surrogate capital market in the place of a non -existent private market'. The SNI was to supply equity capital for economically viable projects with the long-term goal of reselling its shares to private Cameroonians once the projects in question became fully operative. But from its inception, Government has used the SNI as an instrument of national policy; being forced to invest in projects that stood little of no chance of becoming profitable. Mismanagement and diversion of funds have exacerbated the company's difficulties. Few of the SNI's investments have been profitable, notably in consumer goods. Its

72

73

75

Ibid. pp.34 and 35 .

The regulatory environment consists in the rules, which govern the legal and administrative steps to be taken by an entrepreneur to access the formal business sector and to operate therein. Ibid. at pp. 16-39. Akonumbo, A.N., op. cit., pp. 152-167.

Ngwasiri et al, op. cit., pp. 16 and 38.

Ibid. p. 39. 
total portfolio shows a net loss and a negative working position. The crumbling of most of the enterprises the SNI had shares in has been attributed to it. ${ }^{76}$ It is even estimated that up to 1990 the SNI had consumed up to one third of Cameroon's total oil revenues. ${ }^{77}$ Second, the Fonds d'Aide et de Garantie des Credits aux Petites et Moyennes Entreprises (FOGAPE) was created in 1984, to encourage local small and medium sized SMEs enterprises to help boost the national private sector within the framework of the liberalisation of the economic sector. It has equally been a resounding failure. ${ }^{78}$ FOGAPE is [was?] a public establishment of a financial nature endowed with a legal personality and having financial autonomy. Its prime objective was to provide financial and technical assistance to small Cameroonian small and medium sized undertakings in pursuance of the law regulating the banking profession. Thus, it was empowered among other things to: guarantee loans granted by banking, financial and other institutions to Cameroonian SMEs grant loans to them for the funding of their working capital and the replacement and acquisition of new material; provide SMEs with technical assistance; and, to buy shares from them and grants them loans for shares. By June 1995, FOGAPE had guaranteed two hundred and ninety two loans for a total financing of CFA 7575170 francs involving various projects. Unfortunately, FOGAPE has not been able to live up to expectations because of mismanagement and arbitrary guarantee and allocation of loans. Loans in most cases have been granted to non-feasible or fictitious projects under the auspices and intervention of some government officials, 'government friends' or political big wigs. The obvious end result has been that, loans have either been partially or not paid altogether. And in some cases, the beneficiaries have been declared dead or cannot be traced. Worse still, some debtors tendered no collateral security before receiving the loans and this confirms the obscure manner in which they were allocated. FOGAPE has therefore been unable to retrieve about seventy percent of the loans and is now facing imminent liquidation.

Mpakoua, N., (1993), 'Comment la SNI Ravage Notre Economie' .In, La Nouvelle Expression No. 16 de Mars 1993, p. 6. This columnist lists a number of companies where the SNI has left a thumbprint of failure. The companies include, COCAM, CELLUCAM, BATA, and CAMSHIP CAMAIR etc.

USAID [United States Agency for International Development], (1990), Critical Issues for American Investors, Business International, London, pp. 10 and 11.

Decree No. 84/510 of June 13, 1984 created it. It replaced the defunct institution with the same appellation created by Decree No. 75/238 of April 2, 1975 which was attached to the defunct Banque Camerounaise de Développement (BCD). 
From the modalities of privatisation it is clear that Government intends transferring largely to Cameroonian nationals, natural persons or corporate bodies The question is, is it very necessary or safe to privilege nationals for the sake of it? In January 1999, the Prime Minister during a broad inter-ministerial meeting on the private sector proffered facts and statistics indicating that national capital has been privileged in the programme by the structures in charge. ${ }^{79}$ For example, CAMSHIP, SOCAMAC and CEPER were handed over in majority or entirely to nationals, while in the cases of OCB, HEVECAM and CAMRAIL nationals (essentially the personnel of these defunct enterprises), the State and private economic operators held more than thirty percent of the capital. But if nationals more often acquire insufficient shares in such enterprises it is because the State does not provide satisfactory solutions to help nationals attain the standard required for acquiring the enterprises. They neither have the capital, the know-how or the managerial skills. Even where they possess the financial capacity, the technical and managerial skills are more often than not lacking, thus the need to get into a joint venture with a foreign investor for complementation. For example, banana exploitation seems simple but it is a demanding enterprise requiring a great deal of insight and expertise from production to commercialisation through transportation. ${ }^{80}$

However, nationals have been able to buy over certain enterprises either entirely or partially. Thus CEPER was bought over (one hundred percent) by MUPEC; SOCAMAC was privatised to the SAPA a company of the CCEI (Caisse Commune d'Epargne et de Crédit) group; and, the Société de minoterie was privatised to SOCABA, a Company owned by a Cameroonian national. ${ }^{81}$

The solution often resorted to in a bid to fill the gap (financial and technical weakness of nationals) in Cameroon, is to insert a clause whereby the foreign buyer agrees to share the quota privatised with nationals by guaranteeing the latter's share. This was the case with HEVECAM where the majority shareholder agreed to subsequently hand over twenty five percent of the shares to private persons in the following manner: twenty-two percent to private nationals, and three percent to the personnel. Again, as regards the second national telephone system - mobile telephone, the adjudicator would have to finally transfer thirty per cent of the capital of the new structure to nationals. But even this option seems uncer-

Article 1 of the March 29, 1995 Decree for example stipulates that The Commission is responsible amongst other things to propose to the Head of State, all measures susceptible to increase the quota of private national capital in the privatisation process.

80

Ngankam, E.N., op. cit., p. 4.

81

Foute, R.-J., (2000) "La privatisation, facteur de compétivité de l'économie camerounaise" In Cameroun Tribune, $\mathrm{n}^{\mathrm{o}} 7105 / 3394$ of Monday May 23, 2000, at p. 25. 
tain because in the case of CHOCOCAM the ten per cent held on behalf of nationals by the Barry Group has not yet found a ready candidate. ${ }^{82}$

In the case of the CDC that is still to be privatised, the projections are that 5 to 10 percent of the capital will be transferred to the employers and 15 to 20 percent to private nationals.

\subsection{The approach adopted in other African countries with respect to national preference}

Elsewhere, different approaches have been adopted to solve the problem. Some examples are instructive. In Burkina Faso, workers have been aided by government to acquire enterprises slated for privatisation by reducing the selling price by five percent including a possibility of paying by instalments within a maximum period of five years. ${ }^{83}$

In Senegal, take-over by nationals was once guaranteed by a Savings Company and today, by its appurtenance to a regional financial market. This could have been implemented in Cameroon but the ailing banking sector is a possible setback and cannot assure depositors. An alternative solution is for Government to require foreign buyers to make loans to the staff of the enterprises to enable them buy some shares. However, State deafness towards corruption and related ills as embezzlement and mismanagement only help to dampen and stifle such avenues and the problems of privatisation seem concretised. ${ }^{84}$ So, the Burkinabé solution seems most probable to function here.

In Gabon, the privatisation process should encourage nationals as potential buyers because structures have been set up to help them financially acquire shares in the enterprises to be privatised. The Fonds d'Expansions et de Développement des Petites et Moyennes Entreprises (FODEX), a similar structure as the FOGAPE in Cameroon, was created in 1993 and placed under the trusteeship of the Prime Minister. The mission of this structure is to support Small and Medium Sized Enterprises (PME) and, Small and Medium Sized Industries (PMI) by granting loans destined for the creation, expansion and restructuring of enterprises. Its resources are gathered from loans from the African Development Bank (ADB), State subventions, and, loans and subventions from other financial donors. The loans granted by FODEX vary form CFA 500.000 to a maximum of 10 millions francs. ${ }^{85}$ $F O D E X$, a function through various operations and each operation takes care of a particular

82

83

85
Ibid.

Paré, R.D., (1998), 'Comment le Burkina Faso Privatise', in Jeune Afrique Economie No. 257 du 2 au 15 Février, p. xi.

Biloa, A., (1997), 'Les Privatisations Etaient-elles Inévitables?'. In L’Expression op. cit., p. 11.

Continental, (1998), September, October, No. 6, p. 97. 
issue and the percentage subvention for each differs. In each case, the beneficiary is required to raise a certain percentage of the total cost before being subsidised. ${ }^{86}$

It would seem that if Cameroonian nationals cannot take over the enterprises for the reasons mentioned above, and if the Burkinabé or Senegalese formulae cannot be applied for one reason or the other, the best option would be to get into joint ventures with foreigners even if this means encouraging a return of neo-colonialism through a new and subtler means. After all, nationals have been responsible for the death of the same enterprises now slated for privatisation. Within joint ventures they will have to learn and acquire the necessary skills they once lacked!

So far, the tenuous argument against foreign take-over is that foreign investors concentrate only on their new sources of high-level profits. They don't seem involved in any way in the economic or social development of the country. For example, forests in Cameroon are being depleted everyday. But do the timber exploiters bother about the state of roads for example? ${ }^{87}$

It would appear that the honest fear of the privatisation programme by Cameroonians stems from the fact that though the 1990 Ordinance privileges the take-over by nationals, ${ }^{88}$ they have neither the financial nor the technical and managerial capacities. Cameroonians like most Africans lack capital. Even when they do possess it, they do not like to invest in productive projects. Yet, they are spendthrifts and even when they wish to set up businesses they prefer peripheral low value added sectors - bars, nightclubs, dry cleaning etc. ${ }^{89}$

The weakness in domestic savings is a serious set-back but which can be counter balanced by the creation of savings companies and a financial market exclusively designed to facilitate the buying of public companies by nationals. The absence of an adequate financial framework to serve as an incentive to Cameroonians to buy over public enterprises reveals a major weakness of the programme. Yet, the total amount of internal debt owed by public and semi-public enterprises as of 1997 stood at CFA 517.7 billion francs. ${ }^{90}$ This figure does not only necessitate such a programme, but also warrants its success.

Ibid.

87

88

Biloa, A., op. cit., p. 11, supra.

Ibid.

89 Kouassi, R.N., (1998), 'Les Africains Doivent - Ils Avoir Peur de la Privatisation?', Jeune Afrique Economie, No. 274 du 2 au 15 Novembre, p. 118.

90

Kouassi, R.N., (1998), 'Les Africains Doivent -Ils Avoir Peur de la Privatisation?', Jeune Afrique Economie, No. 274 du 2 au 15 Novembre, p. 118. 


\section{Some advantages of Privatisation}

Privatisation may present the following positive traits, if well managed in Cameroon. It enables enterprises to take their appropriate position in the economy and therefore serve as a source of financial assistance to State development projects.

The transfer of property to the private sector supposes an elimination or reduction of State interference in the process of drawing up strategic policies for the enterprise and this would engender efficiency. Reducing or eliminating State interference will help it concentrate more on its traditional functions. ${ }^{91}$ In this wise, responsibilising management organs can guarantee improved performances.

It relinquishes the State from fiscal pressures and the burden of subventions and consequently from the weight of such fiscal pressures and subventions on the State budget. The enterprises can now become financially prosperous on their own, making good use of competent individuals to produce what is meaningful and competitive in the international market. ${ }^{92}$ That is why, the propriety of the sale of an enterprise may not only be judged from the value of the sale but also from the standpoint of investments and development strategies undertaken by the new enterprise, such as, the creation of jobs. For example, though $O C B$ was sold for a token rate in 1995, the new structure realised investments worth CFA 4 billion francs within a short period of time. ${ }^{93}$ However, this is no justification to give away State enterprises for token sums. On the whole if the privatisation programme is well managed it causes a short-term amelioration of State revenue. For example, the sale of HEVECAM alone for CFA 23 billion francs, CAMTEL Mobile for CFA 40.6 billion francs and CFA 6,770 billion francs from some other ten sales were a great source of revenue that eased State budget. The effect of this, it should be noted, is also a long-term amelioration of fiscal gains.

\section{Evaluations and Proposals}

Experience shows that where the privatisation programme is well managed, it ensures the positive performance of the enterprise after privatisation. Thus, the fruits are not just from the value of the actual sale, but also from the fiscal contributions to State coffers that the

91

92

93

Security, health, education, justice etc.

Mainly through reverting to a more enlarged and popular shareholding. This ensures easy access to a bigger number of national assets: Tamba, I., (Thesis), op. cit., pp. 337-338. Also Tamba, I. (1991), 'Un Plan de Privatisation Incomplete'. In, Finances et Développement, vol. 28, No. 1, p. 53.

PNUD (1997) 'Rapport...' op. cit., p. 49 
new enterprise makes. In Burkina Faso for example, forty-two enterprises were slated for privatisation in 1991. By 1997, eighteen had already been completely privatised. These privatised enterprises paid in CFA 694 million francs in 1995 into State coffers, as taxes. ${ }^{94}$ As a result the Burkinabé Government has been able to ease its public debts.

The goal of any privatisation programme should be to increase efficiency, rather than just the performance of the privatised firms. ${ }^{95}$ Most of the enterprises going on privatisation are not known, nor is there usually enough publicity to draw the attention of possible potential buyers. Yet, this is a condition sine qua non to avoid having to sell out the enterprises at give away prices. The values of the sales so far of privatised enterprises are not encouraging as already seen. In other African countries such as Côte d'Ivoire for example the programme appears to be very fruitful. ${ }^{96}$ The programme began there in the Eighties but effectively took off in 1992/93. From then up to the end of 1996 the programme had paid CFA 240 billion francs into State coffers. It was estimated that by the end of 1998 profits would have reached CFA 275 billion francs. The enterprises privatised were not so done for token rates. For example, fifty one percent of the shares of CI-Telecom alone were sold for US \$ 210 million (about CFA 105 billion francs). ${ }^{97}$ These figures indicate that by the time the programme came to its programmed end in the year 2000 [?], there were no regrets $[?]$.

As a booster, the Cameroonian legislator should seek to avoid uncertainty in legislation as earlier seen. The proliferation of texts and, the inherent problems of contradiction, ambiguity and postponement of issues within laws should be avoided. In fact, governments that fail to abide by the rules or change them unpredictably for one privatisation operation, find it difficult to secure buyers for the next. ${ }^{98}$ Consequently the organs that are charged with the privatisation programme should have a stable clear and unfettered mission to accomplish. And as a corollary, those organs should have a wider representation, comprising members of the private sector as well.

To ease the privatisation programme in Cameroon, Government was expected to set up a stock exchange market or accelerate the ongoing plans for the creation of a regional one within the recently established Central African Economic and Monetary Community

Jeune Afrique Economie, (1998) No. 257 du 2 au 15 février, p. IX.

UNCTAD, op. cit., p. 25; The World Bank, (April 1992),"Privatisation: The Lessons of Experience". 
$(C E M A C) .{ }^{99}$ The latter situation was opted for. But there was disagreement amongst the CEMAC member States as to the seat of the market. Gabon was chosen. But Cameroon in particular, viewing its economic potential within the sub-region (as compared to the other States), disagreed and in the in the meantime set up a national stock exchange market that was inaugurated in nation's economic capital of Douala in July 2001. Some African sub regions have fully functional stock exchange markets. The defunct Abidjan Stock Exchange Market - Côte d'Ivoire for example, was replaced in September 1998 by a regional structure known as 'La Bourse Regionale des Valeurs Mobiliers' (BRVM) based in Abidjan Côte d'Ivoire. It is the first regional stock market in the world. This regional financial market is comprised of the eight members of the West African Monetary Union (UEMOA). ${ }^{100}$ The objective of this market among others is to help evaluate and publicise enterprises to be privatised. In addition the market may serve as a medium for informing the public whether a particular enterprise stands the chance of succeeding or not after privatisation. This will help prospective buyers not to indulge in risky undertakings.

For now, the only meaningful way for nationals to be involved in the programme is by getting into joint ventures; joint ventures between nationals (Cameroonians) inter se, or joint ventures between nationals and foreigners. The former formula will enable African or national capital to be invested in Africa and therefore help dispel the fear that privatisation is synonymous to the sale of national sovereignty and the return to neo-colonialism through powerful multinationals. The latter formula may solve the problem of lack of capital and offers the opportunity for national economic operators to benefit from the experience of their foreign counterparts in management techniques, know-how, technology etc. ${ }^{101}$

Furthermore, the banking sector has a vital role to play not only in the privatisation programme but also in attracting foreign private investors generally. Accordingly, this sector should not only be restructured, but Government should make sure that in the restructuring process, emphasis is placed on the availability of liquidity and capital adequacy. The lack of liquidity has fettered banks' capabilities to grant loans or finance investments. For example, the domestic credit provided by Cameroonian banks was valued at 31.2 percent of the GDP in 1990 and 16.4 percent $1996 .{ }^{102}$ Meanwhile, bank and traderelated lending rate in 1990 in million US \$ were -12 in 1990 and -63 in $1996 .{ }^{103}$ This is

Akonumbo, A.N. (1998), op. cit., p. 276; CEMAC replaces the defunct Central African Economic and Customs Union (UDEAC). CEMAC was set-up in Malabo - Equatorial Guinea on June 25, 1999

Bénin, Bukina Faso, Côte d'Ivoire, Guinée-Bissau, Mali, Sénégal and Togo; Jeune Afrique Plus, (1998), No. 1953, du 16 au 22 Juin, pp. 46 and 47.

Kouassi, R.N., op. cit., p. 118, supra.

102 The World Bank, (1998), op. cit., p. 266.

103 Ibid. p. 344. 
because; it is a common feature with Cameroonian banks that they lack liquidity even after being restructured. As such, to take a loan or withdraw personal savings is a whole problem whereas a basic requirement of public confidence in this sector is that depositors should have access to their funds.

Government could undertake measures as clearly defining well in advance corporations to be privatised, the modalities of such privatisation, the setting up of a competent body to manage the programme and to make sure that the body works in transparency, ${ }^{104}$ so that there shall be no discrimination between prospective buyers. The entire public should be sensitised about the programme. Fears of the real intentions of the programme by the public have rendered the exercise fairly unpopular. This is because the average Cameroonian sees privatisation from a social point of view, as synonymous to retrenchment of workers, fall of purchasing power and loss of economic sovereignty. ${ }^{105}$

Finally, as a pointer to success for any meaningful privatisation, only enterprises bringing or capable of bringing revenue are privatisable. That is, even if the enterprise is not sold for a comfortable amount, it should be evident that it is an enterprise capable of generating revenues so as to enable it respect its fiscal obligations. If not, the enterprise should be restructured before being privatised. Else, public authorities risk 'selling dirt-cheap' assets or enterprises whose yields they urgently need to solve a short-term objective - fill gaps in public budgets. ${ }^{106}$ Thus, the programme should not only include loss-making firms but also profitable firms, in order to make the programme more attractive. In fact, one successful privatisation acts as an incentive and vice-versa.

\section{Conclusion}

Largely, privatisation remains an indispensable step towards economic openness and growth. The privatisation process in Cameroon has no doubt been fraught with much difficulty and this has made it ridiculous at one point. This is because attempts have been made to force the pace of the programme without taking into account the structural constraints and absorptive capacity of the economy. Of course, forcing the pace of the programme may instead prove counter-productive, particularly if the privatisation takes place in difficult economic circumstances of stabilisation and the SAP, which the country is experiencing today. The programme must therefore be tackled with a lot of diligence. There must be an existing congenial business climate, because there can be no meaningful flows of invest-

104

ecree of August 30, 1990 op. cit., article. 13, et seq.

105 The programmed privatisation of the CDC is a concrete example.

106 UNCTAD, (1995), Foreign Direct Investment in Africa, United Nations Publications, New York and Geneva, p. 85. 
ment within the framework of the privatisation programme in the absence of an enabling regulatory environment, for example. The elimination of regulatory vices would help strengthen the legal framework, ease the regulatory environment and foster the privatisation programme. As a corollary, there must be a political will to carry out the programme. Since the beginning of the political troubles in Cameroon in 1990 characterised by 'ghost town' operations, there prevails an uneasy calm and investors will not want to dare invest in such a situation because of the fear that the sporadic or intermittent calm may, at any time, lapse into chaos. The climate here is not only based on the regulatory and political stability but also on the existence of a viable available market to welcome the output of the new enterprises. Most western enterprises for example, are geared towards the market economy, such that where there is no available market, they do not invest. Moreover, Government should not only create new policies, but must make sure there is a follow-up to ensure the strict implementation of such policies. 